\title{
Correction to: Harvesting forage of the perennial grain crop kernza (Thinopyrum intermedium) increases root biomass and soil nitrogen cycling
}

\author{
Jennie Y. Pugliese $\mathbb{D}$ - Steve W. Culman • \\ Christine D. Sprunger
}

Published online: 8 March 2019

(C) Springer Nature Switzerland AG 2019

\section{Correction to: Plant Soil}

https://doi.org/10.1007/s11104-019-03974-6

In the published version, the article title was presented incorrectly. The word "cycling" was inadvertently deleted. The correct title is shown here.

The original version has been corrected.

Publisher's note Springer Nature remains neutral with regard to jurisdictional claims in published maps and institutional affiliations. 